\title{
Developmental Anomalies of Bronchial Tree: A Multidetector Computerized Tomography Study
}

\author{
Anomalías del Desarrollo del Árbol Bronquial: \\ un Estudio Mediante Tomografía Computarizada Multidetector
}

\author{
Mahinur Ulusoy"; Ali Sami Kıvrak**; Ismihan Ilknur Uysal ${ }^{* * * *}$; \\ Ahmet Kagan Karabulut ${ }^{* * *}$; Yahya Paksoy ${ }^{* * *} \&$ Zeliha Fazlıgulları ${ }^{* * *}$
}

ULUSOY, M.; KIVRAK, A. S.; UYSAL, I. I.; KARABULUT, A. K.; PAKSOY, Y. \& FAZLIOGULLARI, Z. Developmental anomalies of bronchial tree: A multidetector computerized tomography study. Int. J. Morphol., 31(3):1049-1055, 2013.

SUMMARY: Anomalies of the bronchial tree may cause recurrent acute pulmonary infection and persistent obstruction symptoms. The developmental anomalies of the bronchial tree were presented mostly as case reports with an accompanying anomaly. However in this study, these anomalies were detected in multidetector computerized tomography (MDCT) images which have no reported pathology. Thoracic MDCT images of 400 patients (0-74 years old, 224 male and 176 female) were evaluated. Four tracheal bronchus (1\%) were detected. Three of them were displaced type, one of them was pig bronchus. And two accessory cardiac bronchus $(0,5 \%)$ originated from medial wall of the intermediate bronchus were detected. According to our findings, incidence of tracheal bronchus and accessory cardiac bronchus seems to be higher in Turkish population.

KEY WORDS: Anomaly; Accessory cardiac bronchus; Bronchial tree; Tracheal bronchus; multidetector computerized tomography (MDCT).

\section{INTRODUCTION}

The developmental abnormalities of the bronchial three can be imaged best by the multidetector computerized tomography (MDCT) via multiplanar reconstruction and three-dimensional images (Beigelman et al., 1998; Berrocal et al., 2004). The developmental anomalies are caused by uncompleted separate of trachea esophageal septum in 28th day (Gamsu \& Webb, 1982; Lee et al., 2008). The tracheal bronchus and the accessory cardiac bronchus are the most seen developmental airway anomalies of the trachea (Beigelman et al.; Ghaye et al., 2001; Desir \& Ghaye, 2009).

An lobar or segmental ectopic bronchus originated from wall of the trachea were defined as true tracheal bronchus (Doolittle \& Mair, 2002; Sanchez et al., 2003; Yildiz et al., 2006). It is reported that tracheal bronchus, which is mostly asymptomatic, usually originates $2-6 \mathrm{~cm}$ proximal to the carina and its incidence is $0.1-2 \%$ (Ghaye $e t$ al., 2001; Desir \& Ghaye). Tracheal bronchus originated from lateral wall of the trachea ventilates mostly the apical segment of the right upper lobe.
This anomaly can predispose to infection in related segment of the right lung. Tracheal bronchus can also originate from the main bronchus or the carina (Ghaye et al., 2001). The various types of the tracheal bronchus have been described according to their origin. They are described as "displaced type" when segmental or subsegmental bronchus originates from different place that they should do, and as "supernumerary type" when an additional bronchus originates from the trachea.

As a tracheal bronchus, medial segmental bronchus or the apical segmental bronchus of the right upper lobe bronchus is usually originated from right wall of the trachea. The right upper lobe bronchus with its segmental and subsegmental bronchus originating from the trachea is very rare $(0.2 \%)$ and in that case tracheal bronchus is defined as "pig bronchus" (Ghaye et al., 2001; Yildiz et al.; Ming \& Lin, 2007; Suzuki et al., 2010) (Fig. 1).

Normally the right upper lobe bronchus originates

* Department of Anatomy, Mevlana University Medical Faculty, Konya, Turke.

** Department of Radiology, Selcuk University Medical Faculty, Konya, Turkey.

**** Department of Anatomy, Selcuk University Medical Faculty, Konya, Turkey. 

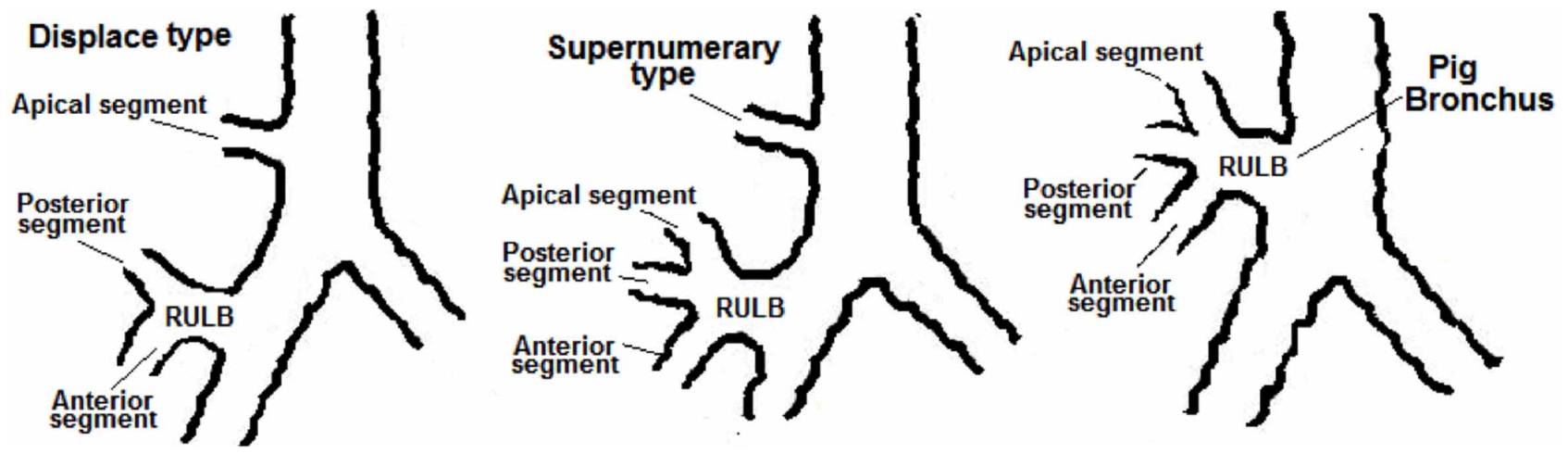

Fig. 1. Types of tracheal bronchi. a) Displaced Type, b) Supernumerary Type, c) Pig bronchus.

above the right pulmonary artery and is described as eparterial bronchus. The left upper lobe bronchus is hyparterial because it is below the left pulmonary artery. If the displaced type tracheal bronchus is proximal to the origin of the superior lobar bronchus, it is called as preparterial in right and eparterial or pre-hyparterial in left; if it is distal to the origin of the superior lobe bronchus, it is known as posteparterial in right and hyparterial in left (McGuinness et al., 1993; Ghaye et al., 1999, 2001).

The accessory cardiac bronchus is an ectopic bronchus which originates from the level of the right upper lobe bronchus extending to the mediastinum and is usually seen in inner wall of the intermedial bronchus. It is reported that this anomaly which are usually blind-ended may be an ectopic small bronchiol or a cystic degeneration or a remnant of a bronchus which ventilated a lobulus or remnant of a parenchymal tissue.

Anomalies of the bronchial tree may cause recurrent acute pulmonary infection and persistent and recurrent obstruction symptoms in patients who are entubed especially in children due to the narrowing of entry of the bronchus. It may cause cough, hemoptysis, bronchiectasis, atelectasis as well (Ghaye et al., 2001; Doolittle \& Mair; Lee et al., 2008).

In our previous study (Ulusoy et al., 2001), we measured the diameter, length and branching angles of trachea and bronchus's in MDCT images of 253 patients. In this study we evaluate these images and additional 147 images of patients for anomalies of trachea and bronchi.

\section{MATERIAL AND METHOD}

This study was approved by the local ethics committee. Thoracic MDCT (Toshiba, Aquilion super 4, Japan) images of 400 patients (0-74 years old, 224 male and
176 female) admitted to the Hospital of the Selcuk University Faculty of Medicine (Konya/Turkey) were evaluated.

The $3.0 \mathrm{~mm}$ thick axial CT images of these patients were transferred to the work station (Vitrea, version 5.2, Vital Images). Minimum-intensity projection (MinIP) images at the axial, coronal and sagittal plane were used to evaluate the developmental anomalies of the trachea and bronchial structures.

\section{RESULTS}

In this study, tracheal bronchus and accessory cardiac bronchus which are the developmental anomalies of the bronchial tree were detected.

Tracheal Bronchus. Four tracheal bronchus (1\%) were detected. Three of them were displaced type, one of them was pig bronchus. There was no supernumerary type.

A displaced type of tracheal bronchus of 51-year-old male patient, right upper lobe apical segment was originated from trachea at $30 \mathrm{~mm}$ proximal to the carina. It was approximately $6.8 \mathrm{~mm}$ in length and $7.1 \mathrm{~mm}$ in diameter and it contributed to ventilation of the right upper lobe apical segment (Figs. 2 and 3).

Other two tracheal bronchus originated from right main bronchus were termed as pre-eparterial bronchus as they originated from proximal to the origin of the right upper lobe bronchus. They originated at about $3 \mathrm{~mm}$ distal to the carina in 11-year-old male (its length and diameter were measured as $14.8 \mathrm{~mm}$ and $6.7 \mathrm{~mm}$ respectively), and at about $15 \mathrm{~mm}$ distal to the carina in 71-year-old female (its length and diameter were measured as $18 \mathrm{~mm}$ and $10 \mathrm{~mm}$ respectively) (Figs. 3 and 4). 


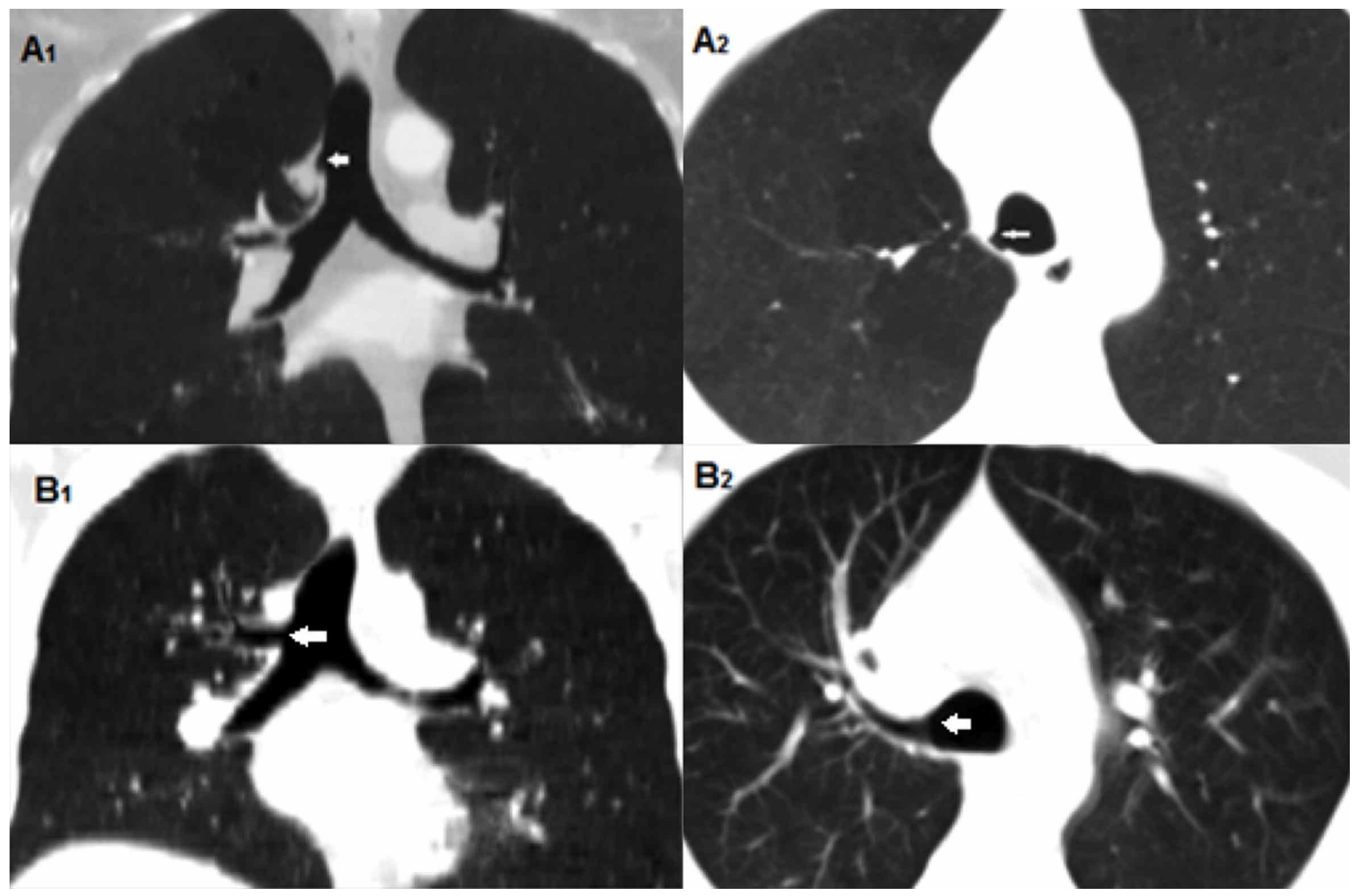

Fig. 2. Displaced type tracheal bronchus (white arrow) in coronal (A1) and axial (A2) plane. Pig bronchus (white arrow) in coronal (B1) and axial (B2) plane.

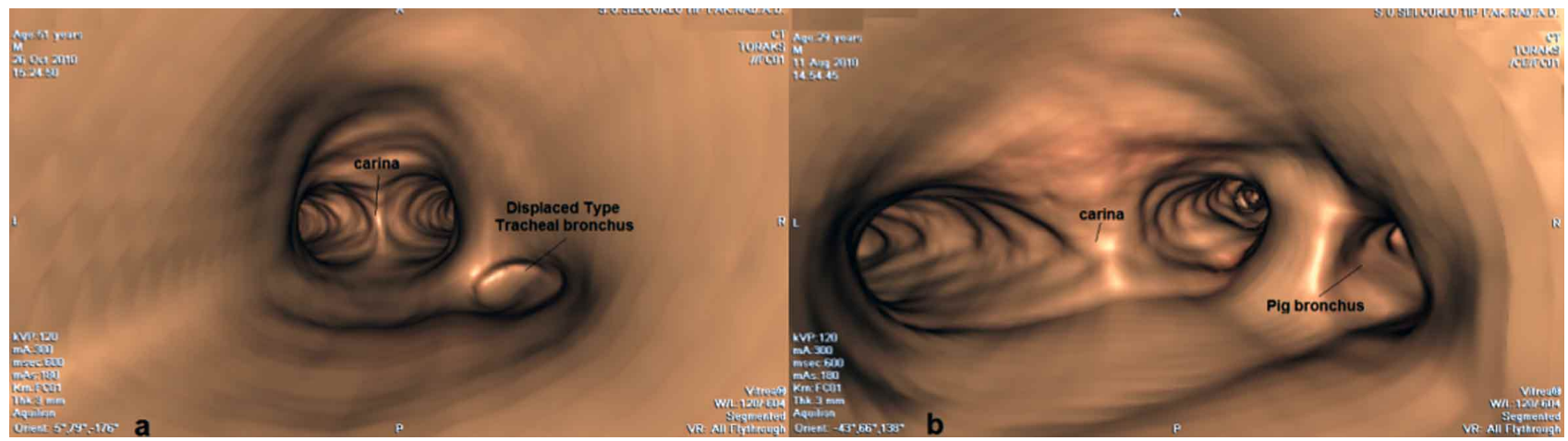

Fig. 3. Virtual bronchoscopy view of displaced type tracheal bronchus (a) and pig bronchus (b).

A pig bronchus, right upper lobe bronchus, was detected in 29-year-old male patient. Its length and diameter were measured as $13.9 \mathrm{~mm}$ and $9.2 \mathrm{~mm}$ respectively. It originated $10 \mathrm{~mm}$ proximal to the carina and ventilated the right upper lobe (Figures 2 and 3).

The Accessory Cardiac Bronchus. The accessory cardiac bronchus originated from medial wall of the intermediate bronchus (opposite to the right upper lobe bronchus) was found in two patients $(0.5 \%)$. They are blind-ended and do not contribute to ventilation of the lungs.

In one of them (54-year-old male), distance of accessory bronchus to the carina was measured as $17.1 \mathrm{~mm}$. Diameter and length of accessory cardiac bronchus were measured as $6.7 \mathrm{~mm}$ and $7.6 \mathrm{~mm}$ respectively. The medial and lower direction angle between the right main bronchus and accessory cardiac bronchus, and the medial and lower 

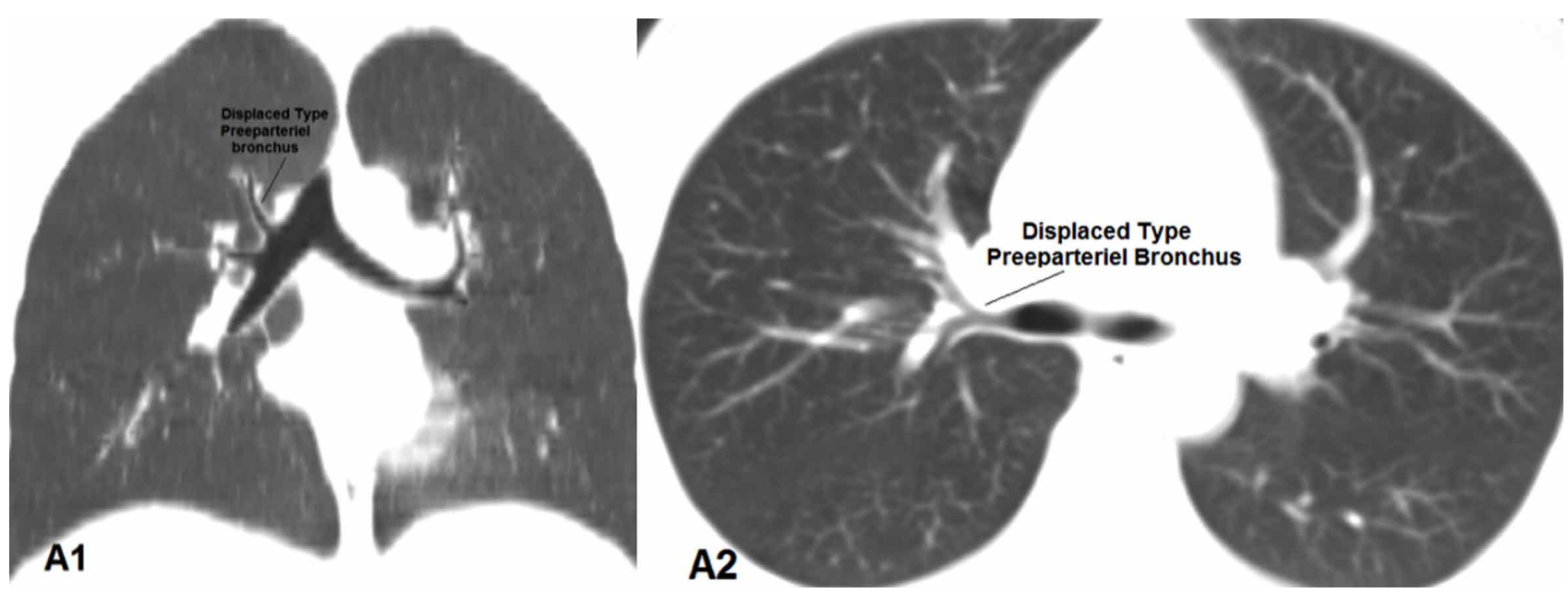

Fig. 4. Displaced type preeparterial bronchus of 11 year-old-child in coronal (A1) and axial (A2) plane.

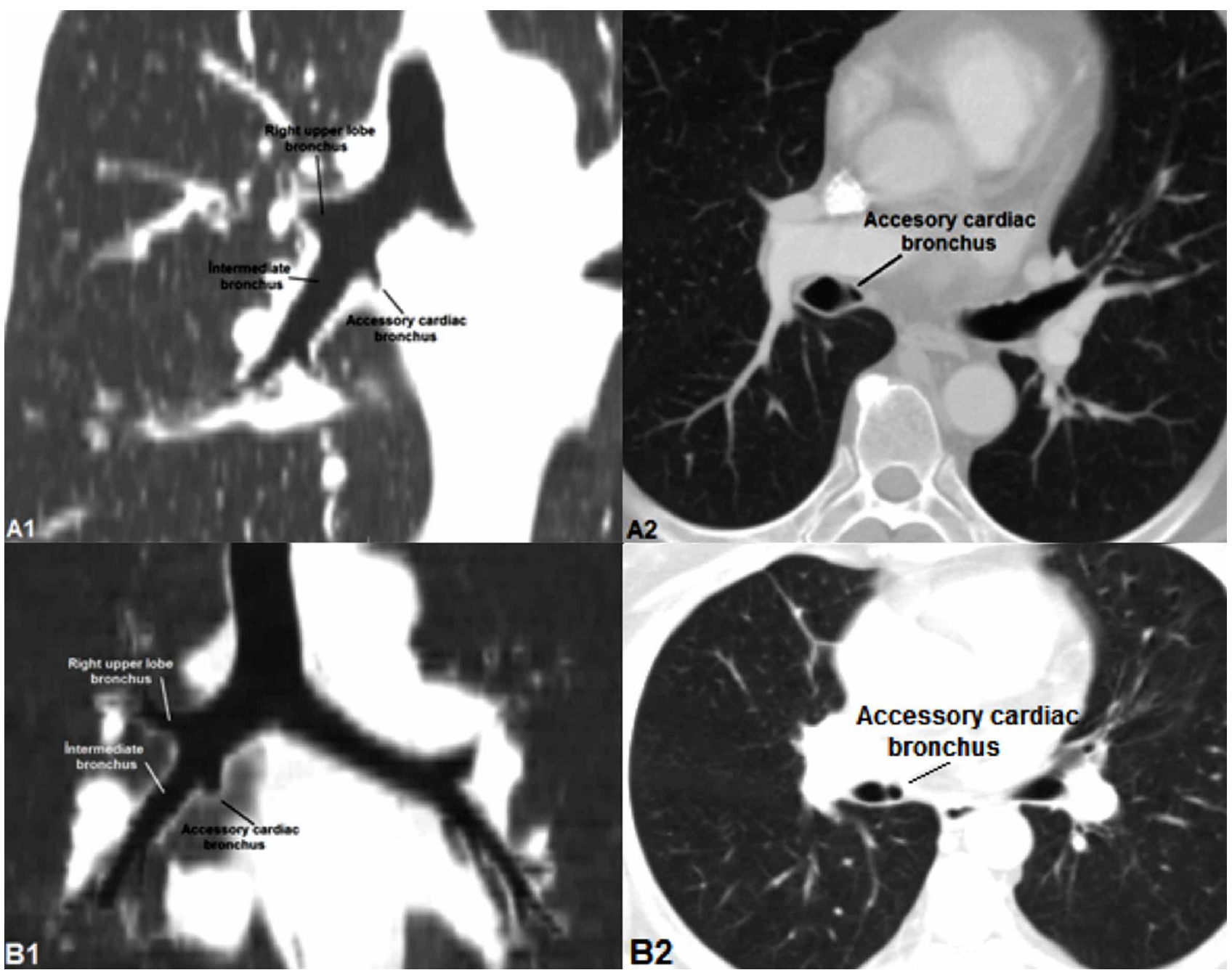

Fig. 5. Accessory cardiac bronchus of 54-year-old man in coronal (A1) and axial (A2) plane and of 45- year-old woman in coronal (B1) and axial (B2) plane. 


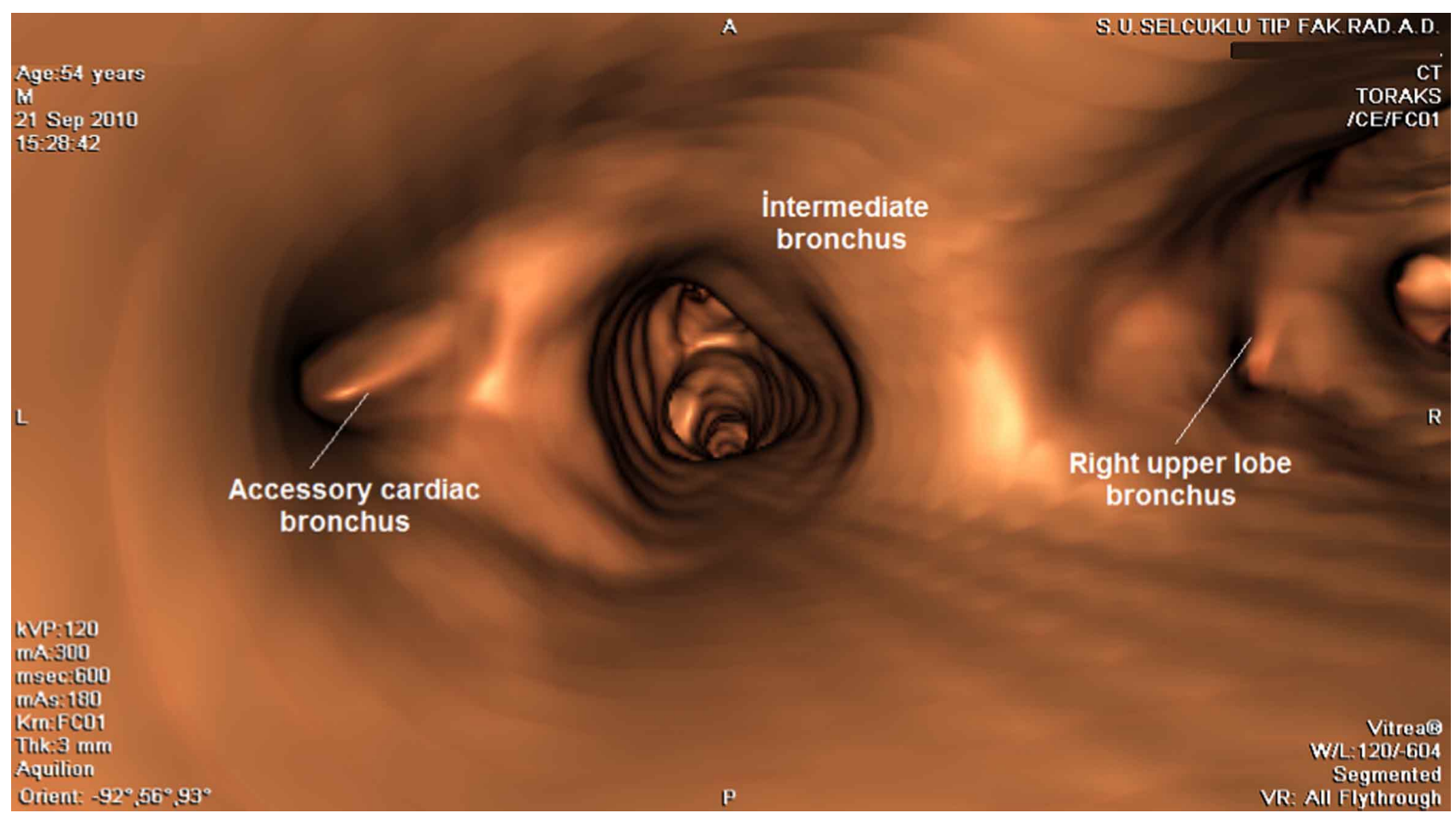

Fig. 6. Virtual bronchoscopy views of accessory cardiac bronchus of 54-year-old man.

direction angle between accessory cardiac bronchus and the intermediate bronchus were measured as $132.3^{\circ}$ and $45.6^{\circ}$ respectively (Figures 4 and 6).

In another patient (45-year-old, female), distance of accessory cardiac bronchus to the carina was measured as $13.5 \mathrm{~mm}$. Diameter and length of accessory cardiac bronchus were measured as $7.6 \mathrm{~mm}$ and $7.3 \mathrm{~mm}$ respectively. The medial and lower direction angle between the right main bronchus and accessory cardiac bronchus, and the medial angle between accessory cardiac bronchus and the intermediate bronchus were measured as $126.4^{\circ}$ and $46.5^{\circ}$ respectively (Figure 5).

\section{DISCUSSION}

The tracheal bronchus and the accessory cardiac bronchus constitute the majority of the bronchial anomalies. The developmental anomalies of the bronchial tree were presented mostly as case reports in literature. In these reports there is usually an accompanying anomaly (Conacher, 2000; Elmaci et al., 2001; Bentala et al., 2002; Chau et al., 2003; Aoun et al., 2004; Heyer et al., 2004; Delpizzo et al., 2006; Ming et al., 2008; Leo et al., 2009; Grosu et al., 2012). In this present study, the developmental anomalies of the bronchial tree were detected in MDCT images that have no reported pathology.

Some researchers studied the developmental anomalies of the bronchial tree on large series. Suzuki et al. detected 30 tracheal bronchus cases out of 9781 MDCT images $(0.39 \%$ male, $0.21 \%$ female). We also detected more cases in males (3 male, 1 female) as in study of Suzuki et al.

Ghaye et al. (2001), reported 35 cases with tracheal bronchus $(0,2 \%)$ out of 17500 MDCT images. In their study, tracheal bronchi originated from the trachea in 8 cases, from the carina in 3 cases and from the bronchi in 24 cases. In our study, the rate of tracheal bronchus was higher than in studies of Suzuki et al. and Ghaye et al. (2001). It seems that asymptomatic tracheal bronchus cases are higher in Turkish population. Ghaye et al. (2001), also reported that $70 \%$ of tracheal bronchus was displaced type and $23 \%$ of them were supernumerary type. Beside they detected that $57 \%$ of these displaced type tracheal bronchus were pre-eparterial type. These findings are in concordance with our results $(75 \%$ displace type, $50 \%$ of them are pre-eparterial).

Ghaye et al. (1999), studied on 11159 images by MDCT with 3D volumetric display and shaded-surface display, and detected 9 cases with accessory cardiac bronchus (0.08\%). They reported that accessory cardiac bronchus originated 
from the intermediate bronchus in 8 cases and from the right main bronchus in 1 case. They also reported that accessory cardiac bronchus was blind-ended in 6 cases and contributed to the ventilated lobulus. Rate of the accessory cardiac bronchus is higher in our study $(0.5 \%)$.
According to our findings, incidence of tracheal bronchus and accessory cardiac bronchus seems to be higher in Turkish population.

ULUSOY, M.; KIVRAK, A. S.; UYSAL, I. I.; KARABULUT, A. K.; PAKSOY, Y. \& FAZLIOGULLARI, Z. Anomalías del desarrollo del árbol bronquial: un estudio mediante tomografía computarizada multidetector. Int. J. Morphol., 31(3):1049-1055, 2013.

RESUMEN: Las anomalías del árbol bronquial pueden causar una infección pulmonar aguda recurrente y síntomas de obstrucción persistente. Las anomalías del desarrollo del árbol bronquial se presentan principalmente como informes de casos con una anomalía de acompañante. Sin embargo, en este estudio se detectaron estas anomalías en las imágenes de tomografía computarizada multidetector (TCMD), donde no se habían informado esta patología. Se evaluaron las imágenes de TCMD torácica de 400 pacientes (0-74 años, 224 hombres y 176 mujeres). Se detectaron cuatro bronquios traqueales (1\%). Tres de ellos fueron de tipo desplazado, uno fue tipo bronquio de cerdo, y dos bronquio cardiaco accesorio $(0,5 \%)$, originados de la pared medial del bronquio intermedio. De acuerdo con nuestros resultados, la incidencia de bronquio traqueal y bronquios cardiacos accesorios parecen ser mayor en la población turca.

PALABRAS CLAVE: Anomalía; Bronquio cardíacos accesorios; Árbol bronquial; Traqueal; Bronquial; Tomografía computarizada multidetector (TCMD).

\section{REFERENCES}

Aoun, N. Y.; Velez, E.; Kenney, L. A. \& Trayner, E. E. Tracheal bronchus. Respir. Care, 49(9):1056-8, 2004.

Beigelman, C.; Howarth, N. R.; Chartrand-Lefebvre, C. \& Grenier, P. Congenital anomalies of tracheobronchial branching patterns: spiral CT aspects in adults. Eur. Radiol., $8(1): 79-85,1998$.

Bentala, M.; Grijm, K.; van der Zee, J. H. \& Kloek, J. J. Cardiac bronchus: a rare cause of hemoptysis. Eur. J. Cardiothorac. Surg., 22(4):643-5, 2002.

Berrocal, T.; Madrid, C.; Novo, S.; Gutiérrez, J.; Arjonilla, A. \& Gómez-León, N. Congenital anomalies of the tracheobronchial tree, lung, and mediastinum: embryology, radiology, and pathology. Radiographics, 24(1):e17, 2004.

Chau, K. W.; Ng, D. K.; Chong, A. S. \& Lau, A. Tracheal bronchus. Hong Kong Med. J., 9(1):71-2, 2003.

Conacher, I. D. Implications of a tracheal bronchus for adult anaesthetic practice. Br. J. Anaesth., 85(2):317-20, 2000.

Delpizzo, K. R.; Joffe, D. C. \& Finkel, J. C. Tracheal bronchus in 10-month-old patient for thoracoscopic resection of congenital cystic adenomatoid malformation. Paediatr. Anaesth., 16(9):997-8, 2006.

Desir, A. \& Ghaye, B. Congenital abnormalities of intrathoracic airways. Radiol. Clin. North Am., 47(2):203-25, 2009.

Doolittle, A. M. \& Mair, E. A. Tracheal bronchus: classification, endoscopic analysis, and airway management. Otolaryngol. Head Neck Surg., 126(3):240-3, 2002.

Elmaci, T. T.; Güler, N.; Aydogan, U. \& Onursal, E. Infantile lobar emphysema and tracheal bronchus in a patient with congenital heart disease. J. Pediatr. Surg., 36(10):1596-8, 2001.

Gamsu, G. \& Webb, W. R. Computed tomography of the trachea: normal and abnormal. AJR Am. J. Roentgenol., 139(2):321-6, 1982.

Ghaye, B.; Kos, X. \& Dondelinger, R. F. Accessory cardiac bronchus: 3D CT demonstration in nine cases. Eur. Radiol., 9(1):45-8, 1999.

Ghaye, B.; Szapiro, D.; Fanchamps, J. M. \& Dondelinger, R. F. Congenital bronchial abnormalities revisited. Radiographics, 21(1):105-19, 2001.

Grosu, H. B.; Morice, R. C.; Betancourt, S. L.; Colomer, A. L. \& Jimenez, C. A. Coexistence of two anatomical bronchial variances. BMJ Case Rep., pii: bcr0120125621, 2012.

Heyer, C. M.; Kagel, T.; Lemburg, S. P.; Nicolas, V. \& Rieger, C. $\mathrm{H}$. Evaluation of tracheobronchial anomalies in children using low-dose multidetector CT: report of a 13 -year-old boy with a tracheal bronchus and recurrent pulmonary infections. Pediatr. Pulmonol., 38(2):168-73, 2004.

Lee, E. Y.; Boiselle, P. M. \& Cleveland, R. H. Multidetector CT evaluation of congenital lung anomalies. Radiology, 247(3):632-48, 2008. 
ULUSOY, M.; KIVRAK, A. S.; UYSAL, I. I.; KARABULUT, A. K.; PAKSOY, Y. \& FAZLIOGULLARI, Z. Developmental anomalies of bronchial tree: A multidetector computerized tomography study. Int. J. Morphol., 31(3):1049-1055, 2013.

Leo, F.; Galetta, D.; Borri, A. \& Spaggiari, L. Segmentectomy for carcinoid arising from an accessory cardiac bronchus. Eur. J. Cardiothorac. Surg., 35(3):537, 2009.

McGuinness, G.; Naidich, D. P.; Garay, S. M.; Davis, A. L.; Boyd, A. D. \& Mizrachi, H. H. Accessory cardiac bronchus: CT features and clinical significance. Radiology, 189(2):563-6, 1993.

Ming, Z.; Hong, S. \& Biao, J. Images in cardiovascular medicine. Asplenia syndrome with bilateral tracheal bronchi. Circulation, 118(2):196-7, 2008.

Ming, Z. \& Lin, Z. Evaluation of tracheal bronchus in Chinese children using multidetector CT. Pediatr. Radiol., 37(12):12304, 2007.

Sánchez, I.; Navarro, H.; Méndez, M.; Holmgren, N. \& Caussade, S. Clinical characteristics of children with tracheobronchial anomalies. Pediatr. Pulmonol., 35(4):288-91, 2003.

Suzuki, M.; Matsui, O.; Kawashima, H.; Takemura, A.; Matsubara, K.; Hayashi, N.; Koda, W. \& Shibata, Y. Radioanatomical study of a true tracheal bronchus using multidetector computed tomography. Jpn. J. Radiol., 28(3):188-92, 2010.

Ulusoy, M.; Uysal, I. I.; Kıvrak, A. S.; Karabulut, A. K.; Ozbek, S. \& Paksoy, Y. The morphometric evaluation of the tracheobronchial tree by multidetector computed tomography. Joint Meeting of Anatomical Societies. Anatomy, 5:S34, 2001.

Yildiz, H.; Ugurel, S.; Soylu, K.; Tasar, M. \& Somuncu, I. Accessory cardiac bronchus and tracheal bronchus anomalies: CTbronchoscopy and CT-bronchography findings. Surg. Radiol. Anat., 28(6):646-9, 2006.

\section{Correspondence to: \\ Dr. Mahinur Ulusoy \\ Department of Anatomy \\ Mevlana University Medical Faculty \\ Konya \\ TURKEY}

Email: mulusoy@mevlana.edu.tr

Received: 30-11-2012

Accepted: 09-06-2013 